\title{
ANALISA POLA BELANJA MENGGUNAKAN ALGORITMA FP GROWTH, SELF ORGANIZING MAP (SOM) DAN K MEDOIDS
}

\author{
Muhammad Imam Ghozali \\ Fakultas Teknik, Program Studi Teknik Informatika \\ Universitas Muria Kudus \\ Email: imam.ghozali@umk.ac.id \\ Ri'fan Zaenal Ehwan \\ SMA N 1 Jakenan Pati \\ Email : revan.ze@gmail.com \\ Wibowo Harry Sugiharto \\ Fakultas Teknik, Program Studi Teknik Informatika \\ Universitas Muria Kudus \\ Email: wibowo.harry@umk.ac.id
}

\begin{abstract}
ABSTRAK
Dalam sebuah bisnis, diperlukan upaya memaksimalkan keuntungan. Diantaranya dengan melakukan promosi. Ketepatan promosi dapat dipelajari dari database sebuah perusahaan ritel utamanya pola belanja pada produk yang biasa dibeli bersamaan. Informasi tentang pola belanja pelanggan yang tidak akurat menyebabkan kebijakan promosi tidak tepat dan efisien.Salah satu upaya lazim untuk memperoleh dan menggali pola belanja pelanggan adalah menggunakan data mining yang dikenal sebagai Knowledge Discovery in Database (KDD). Pendekatan yang biasa digunakan adalah asosiasi. Permasalahannya aturan asosiasi cenderung mengabaikan dataset yang besar. Untuk mengatasi hal tersebut dilakukan klasifikasi barang yang dibeli dan tidak dibeli bersamaan. Algoritma Self Organizing Map (SOM) dan K-Medoids cocok untuk diterapkan dalam mengcluster dataset besar. Penelitian ini menguji kevalidan dan kecepatan algortima Self Organizing Map (SOM) dan K-Medoids jika dikombinasi dengan Frequent Pattern-Growth (FP-Growth).
\end{abstract}

Kata kunci: analisis keranjang pasar, rekomendasi produk, self organizing map, k-medoids, fp-growth.

\section{ABSTRACT}

In a business, it takes effort to maximize profits. Among them with promotions. The accuracy of the promotion can be learned from the database a major retail company spending patterns on products commonly purchased together. Information on customer shopping patterns inaccurate cause improper promotion policy and efisien.Salah a common effort to acquire and explore the shopping patterns of customers is using data mining known as Knowledge Discovery in Databases (KDD). The approach used is association. The problem tends to ignore the rules of association of large datasets. To overcome this problem do the classification of goods purchased and not purchased together. Algorithm Self Organizing Map (SOM) and K-Medoids mengcluster suitable to be applied in large datasets. This study tested the validity and speed algorithms Self Organizing Map (SOM) and K-Medoids when combined with Frequent Pattern-Growth (FP-Growth).

Keywords: market basket analysis, recomendation product, promotion product, association rule mining, k-medoids, fp-growth.

\section{PENDAHULUAN}

Sebuah bisnis diperlukan upaya untuk memaksimalkan keuntungan. Keuntungan tersebut akan dapat diperoleh jika perusahaan dapat memanfaatkan potensi dan peluang usaha yang ada. Pelanggan/ konsumen adalah sumber terbesar pendapatan sebuah usaha. Penjual dapat meningkatkan pendapatan dengan menggunakan strategi pemasaran yang tepat dan akurat. Salah satunya adalah menawarkan barang lain yang kemungkinan besar akan dibeli juga oleh pelanggan secara bersamaan dengan barang yang sudah direncanakan untuk dibeli sebelumnya. Permasalahannya adalah barang apakah yang hampir pasti dibeli oleh pelanggan dan dari manakah informasi barang rekomendasi tersebut kita peroleh? Database toko yang dimiliki toko tersebut dapat dianalisis sehingga memeroleh informasi mengenai produk yang 
sering dibeli secara bersamaan. Metode yang lazim untuk memperoleh dan menggali pola pelanggan tersebut adalah dengan data mining yang biasa dikenal sebagai Knowledge Discovery in Database (KDD). Data mining dapat mengambil informasi yang penting dari database yang besar dan dibutuhkan manusia. Informasi atau pengetahuan tersebut menunjukkan konsep, alur, aturan maupun pola dan bentuk dari sekumpulan data yang berbeda-beda. Data mining dapat diterapkan dalam sebagian besar field.Misalnya untuk membangun trend, memprediksi masa depan, dan menganalisis faktor kunci yang dibutuhkan untuk sebuah permasalahan yang kompleks.

Banyak algoritma yang diusulkan untuk menemukan pola asosiasi dan algoritma pertama yang paling efisien untuk menemukan pola asosiasi adalah apriori [9][10]. Alasan utamanya karena Frequent Pattern-Growth (FP-Growth) merupakan algoritma yang dapat menghemat waktu dan media penyimpanan terlebih untuk database yang besar [12].

Algoritma Apriori adalah algoritma association rule konvensional, yang membutuhkan waktu yang sangat besar saat proses pemindaian database. Hal ini tentu saja berpengaruh pada efisiensi waktu dalam data mining. Algoritma yang diusulkan untuk mengatasi kelemahan tersebut adalah Frequent PatternGrowth (FP-Growth) yang disebut yang tidak perlu untuk menghasilkan generate candidate item sets dan dianggap lebih efisien. Frequent Pattern-Growth (FP-Growth) dibangun dengan membaca kumpulan data satu transaksi pada waktu dan pemetaan setiap transaksi ke dalam bagian Frequent Pattern-Tree (FPTree) [2].

Permasalahan yang muncul selanjutnya dalam aturan asosiasi adalah masalah teknis yang berhubungan dengan teknik rekomendasi yang paling umum dimana aturan asosiasi cenderung mengabaikan itemset besar. Akibatnya rekomendasi item kurang tepat karena informasi tentang produk ritel tidak tersedia [8]. Untuk mengatasi masalah tersebut, atribut yang ada dicluster untuk membentuk kelompok atribut yang sama dan kemudian menentukan pola asosiasi pada masing-masing kelompok Apriori, sehingga dapat mempermudah proses mencari rekomendasi produk. Beberapa algoritma clustering diantara K-Means, Fuzzy C-Means, Self Organizing Map (SOM), K-Medoids [9].

Dalam penelitian ini akan dikomparasikan kombinasi Self Organizing Map (SOM) dengan Frequent Pattern-Growth (FP-Growth), K-Medoids dengan Frequent Pattern-Growth (FP-Growth) dan Frequent Pattern-Growth (FP-Growth) yang berdiri sendiri tanpa di clustering dengan algoritma apapun sebelumnya. Algoritma Self Organizing Map (SOM) dipilih karena Self Organizing Map (SOM) merupakan algoritma clustering model aglomerative dan partitif selain itu juga dikenal sebagai algoritma non liner, teratur, pemetaan dari input data dimensi tinggi ke dalam array dimensi rendah [4][5].. Algoritma K-Medoids dipilih sebagai perbandingan untuk mendampingi Self Organizing Map (SOM) dan Frequent Pattern-Growth (FP-Growth). Pada dasarnya, algoritma clustering yang paling sering dipakai adalah $K$-Means. Namun, K-Means memiliki kekurangan yakni sensitif terhadap outlier dalam data dan hal ini bisa dijawab oleh $K$-Medoids yang tidak terpengaruh terhadap outlier data sehingga hasil clustering menjadi lebih akurat.

\subsection{Analisis Pola Belanja Pasar}

Membahas tentang pola belanja pelanggan tidak bisa dipisahkan dengan Assosiation Rule Mining atau analisis keranjang pasar. Association Rule Mining merupakan salah satu metode data mining yang berfokus pada menemukan pola pembelian dengan mengekstraksi asosiasi atau kejadian dari data transaksional sebuah toko. Analisis keranjang pasar bermula dari transaksi-transaksi yang berisi satu atau lebih barang, dan beberapa informasi sementara dari transaksi tersebut. Untuk melakukan analisis keranjang pasar, berikut langkah-langkah:

1) Tentukan nilai Minimum Support yang diinginkan. Minimum Support merupakan ambang batas minimum jumlah itemset yang diperbolehkan, jika jumlah itemnya di bawah ambang batas maka item tersebut akan dieliminasi.

2) Menetapkan frequent itemset (kumpulan item yang muncul secara bersamaan), dengan cara mengambil itemset yang memiliki frekuensi itemset minimal sebesar Minimum Support sebelumnya.

3) Dari semua frequent itemset, hasilkan aturan asosiasi yang memenuhi nilai Minimum Support.

Analisis keranjang pasar didasarkan pada tiga matrik: Support, Confidence dan Lift. Ketiga matrik tersebut berasal dari catatan transaksi untuk bisnis [1]. Support

Matrik pertama ditetapkan untuk analisis keranjang pasar adalah Support, yang merupakan probabilitas dari asosiasi (probabilitas dari dua item yang dibeli bersama-sama). Support dihasilkan dari berapa kali jumlah item A dan B terjadi bersamaan dalam transaksi yang sama dibagi dengan jumlah total dari transaksi tersebut. Untuk menghitung nilai Support digunakan persamaan (1) sebagai berikut: 


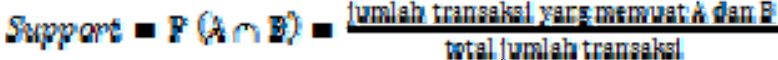

Confidence

Confidence dihasilkan dari seberapa kuat hubungan produk yang sudah dibeli.

Untuk menhitung nilai Confidence digunakan persamaan (2) sebagai berikut:

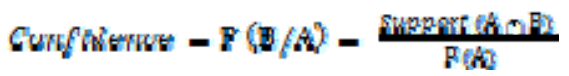

Lift

Lift Ratio mengukur seberapa penting rule yang teleh terbentuk berdasarkan nilai support dan confidence. Lift Ratio merupakan nilai yang menunjukkan kevalidan proses transaksi dan memberikan informasi apakah benar produk A dibeli bersamaan dengan produk B.

Untuk menghitung nilai Lift Ratio digunakan persamaan (3) sebagai berikut:

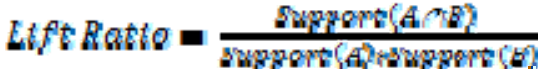

\subsection{Algoritma Self Organizing Map (SOM)}

Self Organizing Map (SOM) merupakan salah satu metode dalam Jaringan Syaraf Tiruan (Neural Network) yang menggunakan pembelajaran tanpa pengarahan (unsupervised learning). Metode pembelajaran tanpa pengarahan tidak memerlukan target, selama proses pembelajaran unit - unit input yang hampir sama dikelompokkan dalam kelompok tertentu yang berada di unit output (cluster units). Arsitektur Self Organizing Map (SOM) terdiri dari 1 lapisan input dan 1 lapisan output. Setiap unit pada lapisan input dihubungkan dengan semua unit di lapisan output dengan suatu bobot keterhubungan yang ditunjukkan pada Gambar 1.

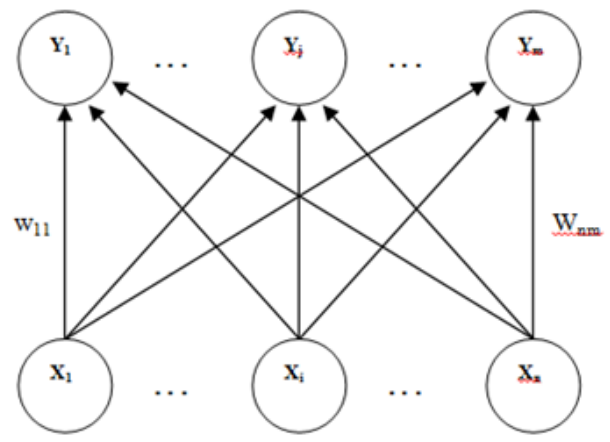

Gambar 1. Algoritma Self Organizing Map (SOM)

\subsection{Algoritma Frequent Pattern-Growth (FP-Growth)}

Algoritma yang biasa dipakai dalam mencari frequent item set antara lain algoritma Apriori dan algoritma Frequent Pattern-Growth (FP-Growth). Pada penelitian ini akan dibahas bagaimana pencarian frequentitemset mengunakan algoritma Frequent Pattern-Growth (FP-Growth). Frequent Pattern Tree (FP-Tree) digunakan bersamaan dengan algoritma Frequent Pattern-Growth (FP-Growth) untuk menentukan frequent item set (data yang paling sering muncul) dari sebuah dataset. Algoritma Frequent Pattern-Growth (FP-Growth) adalah salah satu cara alternatif untuk menemukan himpunan data yang paling sering muncul tanpa menggunakan generasi kandidat [14]. Frequent Pattern-Growth (FP-Growth) membangun konstruksi data Frequent Pattern Tree (FP-Tree) yang sangat dikompresi, dan mengurangi data asli. Algoritma Frequent Pattern-Growth (FP-Growth) melakukan scan database yang sama sebanyak dua kali. Scanning database yang pertama, kita dapat memperoleh frequent 1-item-set, dan scanning database yang kedua, kita dapat memfilter database non-frequent item, selebihnya, Frequent Pattern Tree (FP-Tree) dihasilkan secara bersamaan. Akhirnya, dapat diperoleh aturan asosiasi dengan menggunakan Frequent Pattern Tree (FP-Tree) [13].

Kelemahan Apriori yang selalu melakukan scanning database secara berulang-ulang membuat Apriori ini kurang efektif. Berbeda dengan Frequent Pattern Tree (FP-Tree) yang digunakan bersamaan dengan algoritma Frequent Pattern-Growth (FP-Growth) yang hanya memerlukan dua kali scanning database untuk membuat frequent item set. Dengan menggunakan Frequent Pattern Tree (FP-Tree), algoritma Frequent Pattern-Growth (FP-Growth) dapat langsung mengekstrak frequent Item set dari 
Frequent Pattern Tree (FP-Tree) yang telah terbentuk. Frequent Pattern Tree (FP-Tree) didefinisikan sebagai berikut [14]:

Sebuah root yang diberi label null, sekumpulan sub-tree yang beranggotakan item-item tertentu, dan sebuah tabel frequent header. Setiap simpul dalam Frequent Pattern Tree (FP-Tree) mengandung tiga field, yaitu:

1) Item-name: menginformasikan item yang dipresentasikan oleh simpul tersebut.

2) Count: mempresentasikan jumlah transaksi yang melewati simpul tersebut.

3) Node-Link: penghubung yang menghubungkan simpul-simpul dengan item-name yang sama, atau null jika kosong.

\subsection{Algoritma K-Medoids}

Untuk melakukan clustering dengan metode partisi dapat menggunakan $K$-Means dan $K$-Medoids. $K$-Means merupakan suatu algoritma pengclusteran yang cukup sederhana yang mempartisi dataset kedalam beberapa cluster $\mathrm{k}$. Algoritmanya cukup mudah untuk diimplementasi dan dijalankan, relatif cepat, mudah disesuaikan dan banyak digunakan [14]. Kelemahan-kelemahan dari algoritma K-Means yaitu [20] :

1) Ketika jumlah data yang tidak begitu banyak, pengelompokan awal akan menentukan cluster secara signifikan.

2) Jumlah cluster $\mathrm{K}$ harus ditentukan terlebih dahulu.

3) Cluster yang asli tidak diketahui, dengan menggunakan data yang sama, jika dimasukkan dalam urutan yang berbeda dapat menghasilkan cluster yang berbeda jika jumlah data sedikit.

4) Kelemahan dari aritmatika mean tidak kuat untuk outlier, sangat jauh data dari centroid memungkinkan mempengaruhi centroid yang asli.

Algortima $K$-Medoids, juga dikenal sebagai partitioning around Medoids, adalah varian dari metode K-Means. Hal ini didasarkan pada penggunaan Medoids bukan dari pengamatan mean yang dimiliki oleh setiap cluster, dengan tujuan mengurangi sensitivitas dari partisi yang dihasilkan sehubungan dengan nilai-nilai ekstrim yang ada dalam dataset [3]. Algoritma K-Medoids hadir untuk mengatasi kelemahan Algoritma K-Means yang sensitif terhadap outlier karena suatu objek dengan suatu nilai yang besar mungkin secara substansial menyimpang dari distribusi data [6].

\section{METODOLOGI PENELITIAN}

Penelitian ini menggunakan jenis penelitian eksperimen, dengan melakukan ujicoba terhadap dataset yang telah dikumpulkan. Tahapan-tahapan penelitian ini adalah sebagai berikut:

1) Pengumpulan Data

Pengumpulan data merupakan langkah awal pada suatu penelitian. Data yang digunakan pada penelitian ini adalah data transaksi penjualan Dr. Tariq Mahmood.

2) Pengolahan Data Awal

Pengolahan awal (Pre processing) merupakan tahap untuk mempersiapkan data yang telah diperoleh dari tahap pengumpulan data, yang akan digunakan pada tahap selanjutnya. Pada tahap ini peneliti mengubah format data tanpa mengubah isi data agar mudah untuk diolah menggunakan aplikasi rapidminer.

3) Desain Eksperimen

Tahapan ini akan membahas alurdesain eksperimen yang digunakan pada penelitian supaya prosesnya sistematis dan menghasilkan temuan yang valid.

4) Eksperimen dan Pengujian

Tahapan ini akan mengeksekusi tahapan penelitian dengan teknik pengujian yang akan telah dipersiapkan sebelumnya.

5) Evaluasi Penelitian

Tahapan ini akan membahas hasil evaluasi dari eksperimen yang telah digunakan.

Dataset ini merangkum 304 atribut dimana 303 diantaranya merupakan item barang yang dibeli.

Salah satu datanya menunjukkan ID transaksi penjualan yang dilakukan dalam sebuah supermarket. Terdapat 1362 record transaksi dalam dataset ditunjukkan pada Gambar 2. 


\begin{tabular}{|c|c|c|c|c|c|c|c|c|c|c|c|c|}
\hline 4 & $\mathrm{~A}$ & G & $\mathrm{H}$ & 1 & J & $K$ & L & $\mathrm{M}$ & $N$ & 0 & $P$ & $Q$ \\
\hline 1 & Basket ID & $\begin{array}{l}\text { Sugar } \\
\text { Cookies }\end{array}$ & Onions & Deli Ham & $\begin{array}{l}\text { Dishwasher } \\
\text { Detergent }\end{array}$ & Beets & $\begin{array}{l}40 \text { Watt } \\
\text { Lightbulb }\end{array}$ & $\begin{array}{l}\text { Ice } \\
\text { Cream }\end{array}$ & $\begin{array}{l}\text { Cottage } \\
\text { Cheese }\end{array}$ & $\begin{array}{l}\text { Plain } \\
\text { English } \\
\text { Muffins }\end{array}$ & $\begin{array}{l}\text { Strawberry } \\
\text { Soda }\end{array}$ & $\begin{array}{l}\text { Vanilla Ice } \\
\text { Cream }\end{array}$ \\
\hline 2 & C11867 & false & false & false & false & false & false & false & false & false & false & false \\
\hline 3 & C5096 & false & false & false & false & false & false & false & false & false & false & false \\
\hline 4 & C4295 & false & false & false & false & false & false & false & false & false & false & false \\
\hline 5 & $\mathrm{C} 2837$ & false & false & false & false & false & false & false & false & false & false & false \\
\hline 6 & $\mathrm{C} 2693$ & false & false & false & false & false & false & false & false & false & false & false \\
\hline 7 & C3497 & false & false & false & false & false & false & false & false & false & false & false \\
\hline 8 & $\mathrm{C} 2696$ & false & false & false & false & false & false & false & false & false & false & false \\
\hline 9 & $\mathrm{C} 1895$ & false & false & false & false & false & false & false & false & false & false & false \\
\hline 10 & C9524 & false & false & false & false & false & false & false & false & false & false & false \\
\hline 11 & C9527 & false & false & false & false & false & false & false & false & false & false & false \\
\hline 12 & $\mathrm{C} 8726$ & false & false & false & false & false & false & false & false & false & false & false \\
\hline 13 & C9383 & false & false & false & false & false & false & false & false & false & false & false \\
\hline 14 & $\mathrm{C} 8582$ & true & true & false & false & false & false & true & false & false & false & false \\
\hline 15 & C10133 & false & true & false & false & false & false & false & false & false & false & false \\
\hline 16 & C6983 & false & false & false & false & false & false & false & false & false & false & false \\
\hline 17 & C3641 & false & false & false & false & false & false & false & false & false & false & false \\
\hline 18 & $\mathrm{C} 5246$ & false & false & false & false & false & false & false & false & false & false & false \\
\hline 19 & C10136 & false & false & false & false & false & false & false & false & false & false & false \\
\hline 20 & C7787 & false & false & false & false & false & false & false & false & false & false & false \\
\hline 21 & C3644 & false & false & false & false & false & false & false & false & false & false & false \\
\hline
\end{tabular}

Gambar 2. Data Transaksi Penjualan

\section{Keterangan:}

1) Basket ID seperti C11867, C5096, C4295, C2837, C2693, C2696, C1895, C9524 merupakan ID Transaksi penjualan barang.

2) Sugar Cookies, Onions, Delli Ham, Dishwasher Detergent, Beets, 40 Watt Lightbulb, Ice Cream, Cottage Cheese, Plain English Muffins, Strawberry Soda, Vanila Ice Cream dll merupakan barangbarang yang dijual di Supermarket.

3) False menandakan bahwa barang tersebut tidak dibeli oleh pembeli.

4) True menandakan bahwa barang tersebut dibeli oleh pembeli.

\subsection{Pengolahan Data Awal}

Data akan pada tahap pengolahan data awal diubah menjadi dataset yang sesuai dengan karakteristik algoritma yang akan dilakukan ujicoba. Diantaranya, menyesuaikan format true dan false dalam dataset menjadi data numerik 1 untuk true dan 0 untuk false, agar dapat digunakan dalam proses asosiasi. Tahapan selanjutnya melakukan clustering data tersebut tanpa menambah atribut apapun karena Self Organizing Map (SOM) akan mengcluster tersendiri. Sedangkan untuk K-Medoids ditentukan $k=5$ 


\begin{tabular}{|l|l|l|l|l|l|l|l|l|l|l|l|l|}
\hline 1 & Basket ID & Hair Conc Lemons & Standard & Frozen Cr 98 pct. Fat Sugar Coc Onions & \multicolumn{2}{c}{ Deli Ham } & Dishwash Beets \\
\hline 2 & C11867 & 0 & 0 & 0 & 0 & 0 & 0 & 0 & 0 & 0 & 0 \\
\hline 3 & C5096 & 0 & 0 & 0 & 0 & 0 & 0 & 0 & 0 & 0 & 0 \\
\hline 4 & C4295 & 0 & 0 & 0 & 0 & 0 & 0 & 0 & 0 & 0 & 0 \\
\hline 5 & C2837 & 0 & 0 & 0 & 0 & 0 & 0 & 0 & 0 & 0 & 0 \\
\hline 6 & C2693 & 0 & 0 & 0 & 0 & 0 & 0 & 0 & 0 & 0 & 0 \\
\hline 7 & C3497 & 0 & 0 & 0 & 0 & 0 & 0 & 0 & 0 & 0 & 0 \\
\hline 8 & C2696 & 0 & 0 & 0 & 0 & 0 & 0 & 0 & 0 & 0 & 0 \\
\hline 9 & C1895 & 0 & 0 & 0 & 0 & 1 & 0 & 0 & 0 & 0 & 0 \\
\hline 10 & C9524 & 0 & 0 & 0 & 0 & 0 & 0 & 0 & 0 & 0 & 0 \\
\hline 11 & C9527 & 0 & 0 & 0 & 0 & 0 & 0 & 0 & 0 & 0 & 0 \\
\hline 12 & C8726 & 0 & 0 & 0 & 0 & 0 & 0 & 0 & 0 & 0 & 0 \\
\hline 13 & C9383 & 0 & 0 & 0 & 0 & 0 & 0 & 0 & 0 & 0 & 0 \\
\hline 14 & C8582 & 0 & 0 & 0 & 0 & 0 & 1 & 1 & 0 & 0 & 0 \\
\hline 15 & C10133 & 0 & 0 & 0 & 0 & 1 & 0 & 1 & 0 & 0 & 0 \\
\hline 16 & C6983 & 0 & 0 & 0 & 0 & 0 & 0 & 0 & 0 & 0 & 0 \\
\hline 17 & C3641 & 1 & 0 & 0 & 0 & 0 & 0 & 0 & 0 & 0 & 0 \\
\hline 18 & C5246 & 0 & 0 & 0 & 0 & 0 & 0 & 0 & 0 & 0 & 0 \\
\hline 19 & C10136 & 0 & 0 & 0 & 0 & 0 & 0 & 0 & 0 & 0 & 0 \\
\hline
\end{tabular}

\section{Gambar 3. Dataset Setelah Diubah Menjadi Numerik}

\subsection{Desain Eksperimen}

Eksperimen pada penelitian ini adalah menggunakan Self Organizing Map (SOM) dan Frequent Pattern-Growth (FP-Growth), kemudian dengan data yang sama menerapkan algoritma K-Medoids dan Frequent Pattern-Growth (FP-Growth) serta mengujinya juga dataset langsung diasosiasi dengan Frequent Pattern-Growth (FP-Growth) tanpa diawali dengan clustering terlebih dahulu. Desain untuk eksperimen ini tunjukkan pada gambar 4.

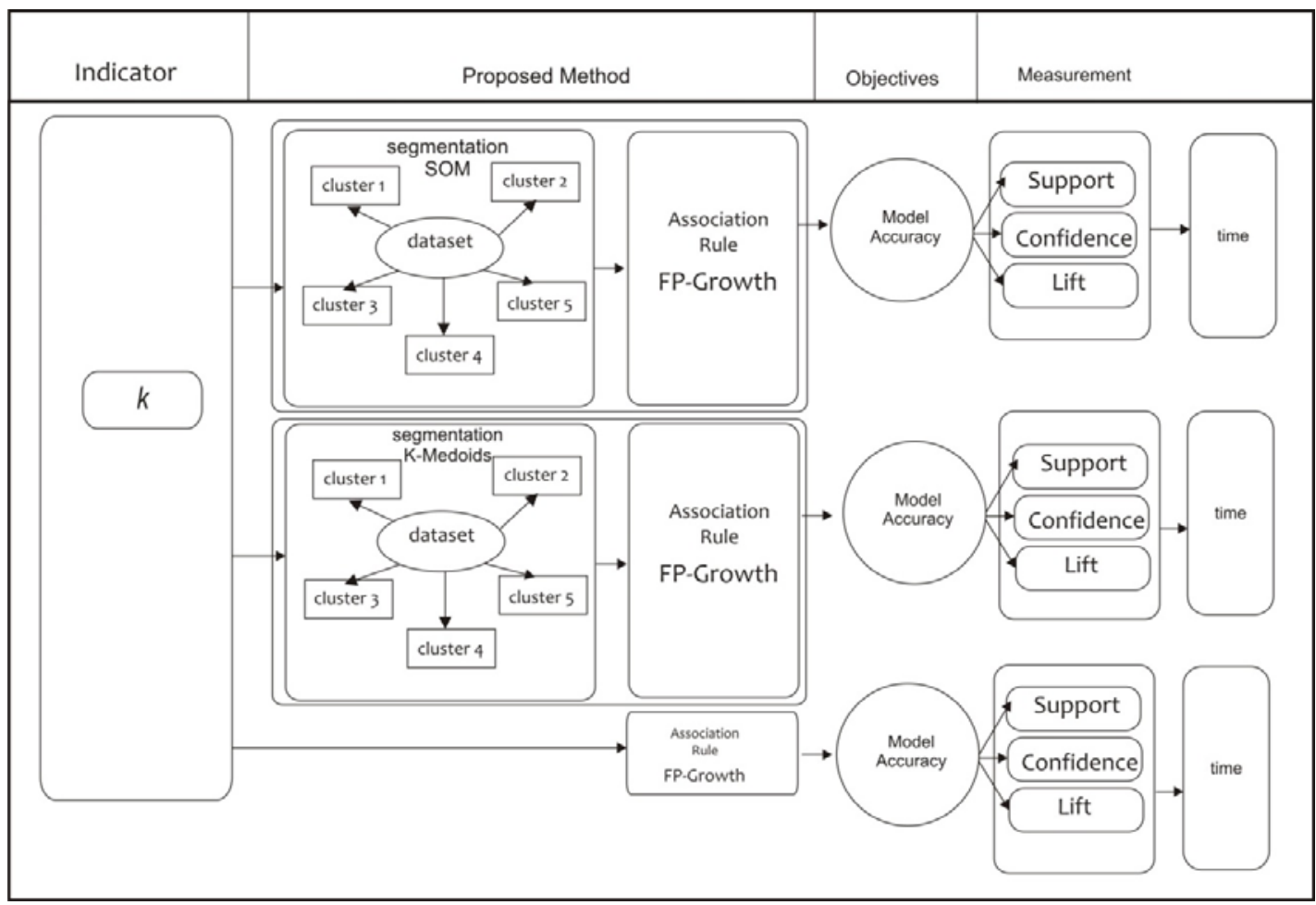

Gambar 4. Desain Eksperimen Penggabungan Algoritma

Eksperimen ini diawali dengan menerapkan algoritma Self Organizing Map (SOM) untuk clustering dan algoritma Frequent Pattern-Growth (FP-Growth) untuk pendekatan asosiasi. Dalam Algoritma Self Organizing Map (SOM) dataset dicluster secara alamiah tanpa ditentukan dulu jumlahnya. Proses 
clustering dilakukan supaya data yang diasosiasi menjadi lebih kecil sehingga pola yang diperoleh menjadi lebih akurat. Tiap cluster yang terbentuk kemudian diasosiasi dengan Frequent Pattern-Growth (FP-Growth) untuk membuat pola belanja pelanggan. Dalam proses asosiasi ini akan diukur support, confidence, dan lift ratio. Setelah itu, dicatat waktu total yang dibutuhkan dari masing-masing tahapan. Eksperimen diulangi dengan mengganti algoritma clustering Self Organizing Map (SOM) dengan $K$ Medoids dan proses asosiasi tetap menggunakan Self Organizing Map (SOM). Jumlah cluster yang dibuat yakni 5 cluster. Kemudian masing-masing cluster di asosiasi dengan algoritma Self Organizing Map (SOM) untuk diukur support, confidence, dan lift ratio. Kemudian waktu proses masing-masing tahapan dicatat. Akurasi dan total waktu proses clustering hingga asosiasi dari tahapan 1 yakni Self Organizing Map $(\mathrm{SOM})+$ Frequent Pattern-Growth (FP-Growth) dibandingkan dengan tahapan 2 yakni K-Medoids + Frequent Pattern-Growth (FP-Growth) kemudian dibandingkan dengan akurasi dan waktu yang diperlukan jika menggunakan Frequent Pattern-Growth (FP-Growth) saja. Kemudian disimpulkan diantara ketiganya terkait akurasi dan efisiensi waktunya.

\subsection{Evaluasi Penelitian}

Hasil akurasi untuk menentukan rekomendasi produk kepada pelanggan yang didapat dari penelitian ini dapat diukur dengan menggunakan Lift Ratio. Lift Ratio merupakan nilai yang menunjukkan kevalidan proses transaksi dan memberikan informasi apakah benar produk A dibeli bersamaan dengan produk B. Sebuah transaksi dikatakan valid jika mempunyai nilai Lift Ratio lebih dari 1, yang berarti bahwa dalam transaksi tersebut, produk A dan B benar-benar dibeli secara bersamaan. Lift Ratio mengukur seberapa penting rule yang telah terbentuk berdasarkan nilai support dan confidence. Evaluasi rekomendasi produk untuk pelanggan ditunjukkan di gambar 5.

\begin{tabular}{|c|c|c|c|c|c|}
\hline No. & Premises & Conclusion & Suppor & Confidence & Lift । \\
\hline 1 & Whole Corn & Hair Conditioner & 0.970 & 0.976 & 1.006 \\
\hline 2 & Orange Flavored Fruit Bars & Hair Conditioner & 0.970 & 0.976 & 1.006 \\
\hline 3 & Whole Corn & Orange Flavored Fruit Bars, Hair Conditioner & 0.970 & 0.976 & 1.006 \\
\hline 4 & Orange Flavored Fruit Bars & Whole Corn, Hair Conditioner & 0.970 & 0.976 & 1.006 \\
\hline 5 & Whole Corn, Orange Flavored Fruit Bars & Hair Conditioner & 0.970 & 0.976 & 1.006 \\
\hline 6 & Whole Corn & Orange Flavored Fruit Bars & 0.994 & 1 & 1.006 \\
\hline 7 & Orange Flavored Fruit Bars & Whole Corn & 0.994 & 1 & 1.006 \\
\hline 8 & Hair Conditioner & Whole Corn & 0.970 & 1 & 1.006 \\
\hline 9 & Hair Conditioner & Orange Flavored Fruit Bars & 0.970 & 1 & 1.006 \\
\hline 10 & Hair Conditioner & Whole Corn, Orange Flavored Fruit Bars & 0.970 & 1 & 1.006 \\
\hline 11 & Whole Corn, Hair Conditioner & Orange Flavored Fruit Bars & 0.970 & 1 & 1.006 \\
\hline 12 & Orange Flavored Fruit Bars, Hair Conditioner & Whole Corn & 0.970 & 1 & 1.006 \\
\hline
\end{tabular}

Gambar 5. Evaluasi Rekomendasi Produk Dengan Support, Confidence, Lift

Setelah ditemukan Support, Confidence, Lift kemudian dicatat pada masing-masing proses untuk diketahui seberapa efisien waktu yang diperlukan dari pengolahan dataset hingga menjadi sebuah pola belanja pelanggan. Kemudian akan disimpulkan tahapan mana yang memiliki tingkat kevalidan paling baik dan tahapan mana yang memiliki waktu proses paling efisien.

\section{HASIL DAN PEMBAHASAN}

\subsection{Clustering Data dengan K-Medoids}

Dalam $k$-medoids kita tentukan menjadi 5 cluster $(\mathrm{k})$. Penentuan $k=5$ ini dilakukan supaya lebih mudah didapatkan hasilnya karena keterbatasan kemampuan PC. Hasil dari proses clustering tersebut akan di eksport dalam bentuk file terpisah untuk masing-masing hasil cluster. Proses clustering data ditunjukkan pada gambar 6, dan hasil clustering data ditunjukkan pada gambar 7 . 


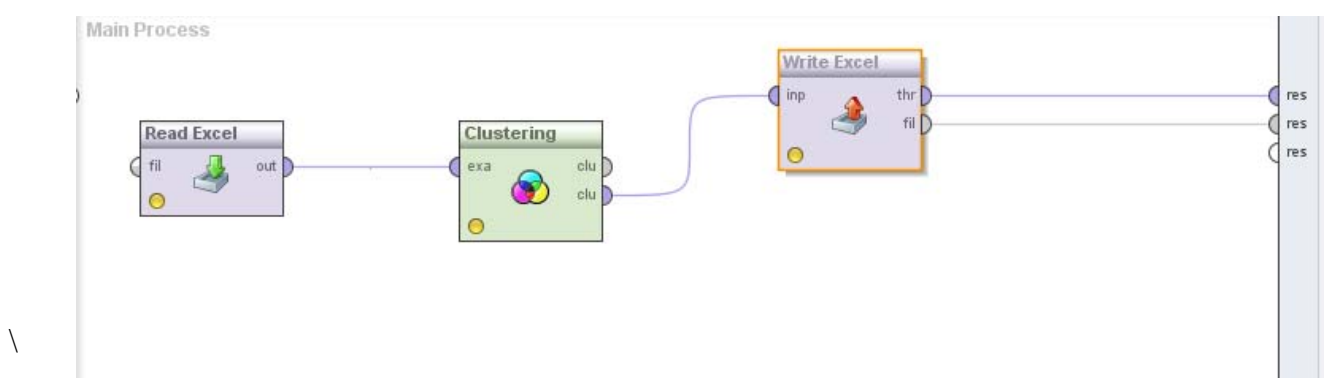

\section{Gambar 6. Proses Clustering Data}

\begin{tabular}{|c|c|c|c|c|c|c|c|c|c|c|c|c|c|c|c|c|c|c|c|}
\hline 4 & A & B & C & D & E & $\mathrm{F}$ & G & H & 1 & J & K & $L$ & & M & $\mathrm{N}$ & 0 & $P$ & $Q$ & $R$ \\
\hline 1 & Basket ID & Cluster & ir Conditio & Lemons & Standaro & Frozen $\mathrm{Cr}$ & 98pct. Fat & Sugar Coc & c Onions & Deli Ham & Dishwash & $\mathrm{h}$ Beets & & 40 Watt Li I & ce crear & Cottage $\mathrm{C}$ & - Plain Eng & Strawber & Vanilla Icc $P c$ \\
\hline 2 & Basket ID & cluster_0 & 0 & & 0 & 0 & 1 & 1 & & 0 & 0 & & 0 & 0 & 0 & 0 & 0 & 0 & 0 \\
\hline 3 & C5252 & cluster_0 & 1 & & 1 & 0 & 1 & 0 & 1 & 0 & 1 & & 0 & 0 & 1 & 1 & 0 & 0 & 0 \\
\hline 4 & C3659 & cluster_o & 1 & c & 0 & 0 & 1 & 0 & 0 & 0 & 0 & & 0 & 0 & 0 & 0 & 0 & 0 & 1 \\
\hline 5 & C4478 & cluster_0 & 1 & & 1 & 0 & 1 & 0 & & 0 & 0 & & 1 & 0 & 0 & 1 & 0 & 0 & 0 \\
\hline 6 & C887 & cluster_o & 0 & c & 0 & 1 & 0 & 1 & 1 & 0 & 1 & & 0 & 0 & 0 & 1 & 0 & 0 & 0 \\
\hline 7 & C7995 & cluster_o & 0 & c & 0 & 0 & 0 & 0 & 0 & 1 & 1 & & 0 & 1 & 0 & 0 & 1 & 1 & 1 \\
\hline 8 & C4694 & cluster_0 & 0 & c & 0 & 0 & 1 & 1 & 1 & 0 & 0 & & 0 & 0 & 0 & 0 & 0 & 0 & 0 \\
\hline 9 & C8987 & cluster_0 & 1 & & 1 & 0 & 1 & 1 & 1 & 0 & 0 & & 0 & 0 & 0 & 0 & 0 & 0 & 0 \\
\hline 10 & C2177 & cluster_0 & 1 & c & 0 & 0 & 1 & 0 & 1 & 0 & 0 & & 0 & 0 & 0 & 1 & 0 & 0 & 0 \\
\hline 11 & C2543 & cluster_0 & 1 & & 1 & 1 & 0 & 1 & 1 & 0 & 0 & & 0 & 1 & 1 & 0 & 0 & 0 & 0 \\
\hline 12 & C9233 & cluster_0 & 0 & c & 0 & 0 & 1 & 1 & 0 & 0 & 0 & & 0 & 0 & 0 & 0 & 0 & 0 & 0 \\
\hline 13 & C7493 & cluster_0 & 0 & 0 & 0 & 0 & 1 & 0 & 0 & 0 & 0 & & 0 & 0 & 0 & 0 & 0 & 0 & 0 \\
\hline 14 & C7646 & cluster_0 & 0 & c & 0 & 0 & 1 & 0 & 0 & 0 & 0 & & 0 & 0 & 0 & 0 & 0 & 0 & 0 \\
\hline 15 & C1784 & cluster_0 & 0 & & 0 & 0 & 1 & 1 & 0 & 0 & 0 & & 1 & 0 & 0 & 1 & 0 & 0 & 0 \\
\hline 16 & C5303 & cluster_o & 1 & c & 0 & 0 & 1 & 0 & 0 & 0 & 1 & & 1 & 0 & 1 & 0 & 0 & 0 & 0 \\
\hline 17 & C9623 & cluster_0 & 1 & & 1 & 0 & 0 & 0 & 0 & 0 & 0 & & 0 & 0 & 0 & 1 & 0 & 0 & 0 \\
\hline 18 & C959 & cluster_0 & 0 & c & 0 & 0 & 1 & 1 & 1 & 1 & 0 & & 1 & 0 & 0 & 0 & 0 & 0 & 0 \\
\hline 19 & C5501 & cluster_0 & 0 & & 1 & 0 & 0 & 1 & 0 & 0 & 1 & & 0 & 0 & 0 & 1 & 0 & 0 & 0 \\
\hline 20 & C4706 & cluster_0 & 1 & & 1 & 0 & 1 & 0 & 1 & 0 & 1 & & 0 & 0 & 0 & 0 & 0 & 0 & 0 \\
\hline 21 & C12002 & cluster_o & 1 & c & 0 & 0 & 1 & 0 & 0 & 0 & 0 & & 0 & 0 & 0 & 0 & 0 & 0 & 0 \\
\hline 22 & C 3770 & cluster_0 & 1 & & 1 & 0 & 1 & 1 & 1 & 0 & 0 & & 0 & 0 & 0 & 0 & 0 & 1 & 0 \\
\hline 23 & C3788 & cluster_o & 1 & c & 0 & 0 & 0 & 0 & 0 & 0 & 1 & & 0 & 0 & 0 & 0 & 0 & 0 & 0 \\
\hline 24 & C6347 & cluster_0 & 1 & & 1 & 0 & 1 & 1 & 1 & 0 & 0 & & 1 & 0 & 1 & 0 & 0 & 0 & 0 \\
\hline
\end{tabular}

Gambar 7. Hasil Clustering Data

Setelah hasil cluster didapat, yakni cluster 0 , cluster 1 , cluster 2, cluster 3, cluster 4 kemudian diurutkan/ sorting dan dipisahkan menjadi 5 file untuk kemudian di lakukan proses asosiasi dengan Frequent Pattern-Growth (FP-Growth). Hasil dari cluster menggunakan K-Medoids:

Cluster 0: 32 items

Cluster 1: 2 items

Cluster 2: 2 items

Cluster 3: 2 items

Cluster 4: 1323 items

Total number of items: 1361

Selama 28,20menit

\subsection{Clustering Data dengan Self Organizing Map (SOM)}

Rancangan Proses clustering data dengan Self Organizing Map (SOM) ditunjukkan pada gambar 8.

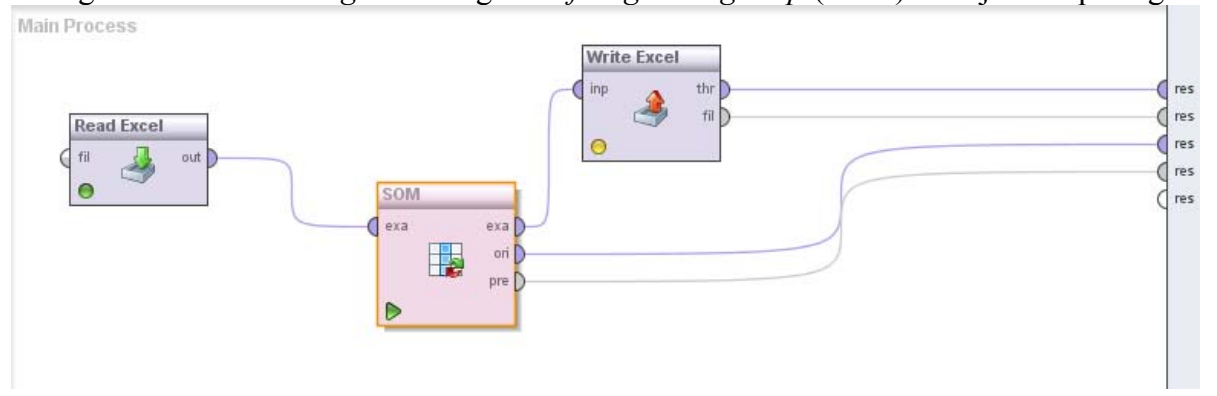

Gambar 8. Rancangan Cluster Data dengan Self Organizing Map (SOM) 
Cluster data dilakukan dengan Self Organizing Map (SOM) terbagi menjadi 2, dari rancangan cluster data tersebut didapatkan hasil yang ditunjukkan pada gambar 9.

\begin{tabular}{|l|l|l|}
\hline Row No. & \multicolumn{1}{c}{ SOM_0 } & \multicolumn{1}{r|}{ SOM_1 } \\
\hline 1 & 10 & 24 \\
\hline 2 & 10 & 24 \\
\hline 3 & 10 & 24 \\
\hline 4 & 10 & 24 \\
\hline 5 & 10 & 24 \\
\hline 6 & 10 & 24 \\
\hline 7 & 10 & 24 \\
\hline 8 & 10 & 24 \\
\hline 9 & 10 & 24 \\
\hline 10 & 10 & 24 \\
\hline 11 & 10 & 24 \\
\hline 12 & 10 & 24 \\
\hline 13 & 10 & 24 \\
\hline 14 & 10 & 24 \\
\hline 15 & 10 & 24 \\
\hline
\end{tabular}

Gambar 9. Rancangan Cluster Data dengan Self Organizing Map (SOM)

\subsection{Asosiasi Cluster Data Penjualan}

Setiap cluster akan dilakukan asosiasi dengan Frequent Pattern-Growth (FP-Growth) untuk menghasilkan rekomendasi produk. Proses asosiasi cluster ditunjukkan pada gambar 10.

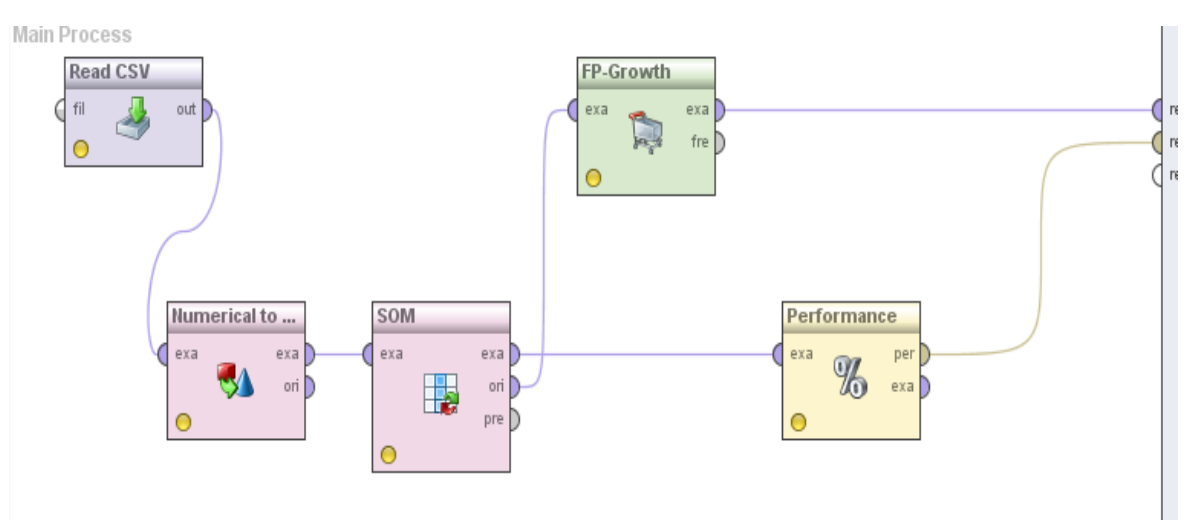

\section{Gambar 10. Hasil Asosiasi Cluster Data Penjualan}

Setelah proses clustering dilakukan, didapatkan 5 cluster. Cluster yang terbentuk dijadikan sebagai dataset baru yang lebih kecil daripada dataset sebelumnya. Kemudian setiap cluster akan dilakukan pendekatan asosiasi menggunakan algoritma Frequent Pattern-Growth (FP-Growth) untuk menganalisis keranjang pasar. Dengan dataset yang lebih kecil tujuan untuk meningkatkan akurasi dalam rekomendasi produk, sedangkan untuk perbandingan digunakan algoritma apriori.

\section{KÉSIMPULAN}

Hasil akurasi untuk menentukan rekomendasi produk kepada pelanggan yang didapat dari penelitian ini dapat diukur dengan menggunakan Lift Ratio. Lift Ratio merupakan nilai yang menunjukkan kevalidan proses transaksi dan memberikan informasi apakah benar produk A dibeli bersamaan dengan produk B. Sebuah transaksi dikatakan valid jika mempunyai nilai Lift Ratio lebih dari 1, yang berarti bahwa dalam transaksi tersebut, produk A dan B benar-benar dibeli secara bersamaan [6]. Lift Ratio mengukur seberapa penting rule yang telah terbentuk berdasarkan nilai support dan confidence. Untuk eksperimen ditentukan nilai Minimum Support adalah 10\% - 100\% dan nilai Minimum Confidence 10\% - 100\%. 


\section{DAFTAR PUSTAKA}

[1] B. Hoanca, "Using Market Basket Analysis to Estimate Potential Revenue Increases for a Small University Bookstore," Information Systems, vol. 1822, 2011, pp. 1-11.

[2] C. Wang, W. Lee, and C. Pang, "Applying Fuzzy FP-Growth to Mine Fuzzy Association Rules," Engineering and Technology, 2010.

[3] C. Vercellis, Business Intelligence: Data Mining and Optimization for Decision Making, Milan: WILEY, 2009.

[4] Endy, Charles Lim, Kho I Eng, AntoSatriyoNugroho, 2010, Implementation of intelligent searchingUsing self-organizing map for webmining used In document containing information in Relation to cyber terrorism,Second International Conference on Advances in Computing, Control, and Telecommunication Technologies.

[5] Juha Vesanto and Esa Alhoniemi,Clustering of the Self-Organizing Map, IEEE Transactions on Neural Networks, 2000.

[6] J. Han and M. Kamber, Data Mining: Concepts and Techniques, Morgan Kaufmann, 2006.

[7] K. Christidis, D. Apostolou, and G. Mentzas, "Exploring Customer Preferences with Probabilistic Topics Models," Work, 2010, pp. 1-13.

[8] L. Gordon, "Leading Practices in Market Basket Analysis," Strategy, vol. 94022, 2008.

[9] M. Plasse, N. Niang, G. Saporta, A. Villeminot, and L. Leblond, "Combined use of association rules mining and clustering methods to find relevant links between binary rare attributes in a large data set," Computational Statistics \& Data Analysis.

[10] M. Ykhlef, "A Quantum Swarm Evolutionary Algorithm for mining association rules in large databases," Journal of King Saud University - Computer and Information Sciences, vol. 23, 2011, pp. 1-6.

[11] S. Guglani, G. Gupta, and M. Dhanda, "Way to Improve K-Means Algorithm by Using Various Attributes," (IJAEST) International Journal of Advanced Engineering Sciences and Technologies, vol. 7, 2011, pp. $330-336$.

[12] Yongmei Liu and Yong Guan, "FP-Growth Algoritm For Appliaction in Research of Market Basket Analysis,”2008, Capital Normal University, Beijing, China 2008.

[13] Y. Liu and Y. Guan, "FP-Growth Algorithm for Application in Research of Market BasketAnalysis," Design, 2008.

[14] X. Wu, V. Kumar, J.R. Quinlan, J. Ghosh, Q. Yang, H. Motoda, G.J. Mclachlan, A. Ng. 